\title{
Teachers' Awareness towards 21st Century Teaching and Its Implementation (Administrators' Perspective)
}

\author{
Lim Chong Ewe \\ School of Education College of Arts and Sciences, \\ Universiti Utara Malaysia \\ Sintok, Malaysia \\ Limce89@gmail.com
}

\author{
Faizahanibinti Ab Rahman \\ School of Education College of Arts and Sciences, \\ Universiti Utara Malaysia \\ Sintok, Malaysia \\ faizahani@uum.edu.my
}

\author{
Lawal Abdul Faragai \\ School of Education College of Arts and Sciences, \\ Universiti Utara Malaysia \\ Sintok, Malaysia \\ lawalfaragai@yahoo.com
}

\begin{abstract}
There has been many theories and approaches that has been suggested and implemented by teachers around the globe to ensure the effectiveness of the teaching and learning process. In recent years, Malaysia, along with other countries around the globe, has shifted the nation's educational policies and implementation towards the 21 st century teaching and learning. This paper focuses on school administrators' awareness of 21 st century skills and the implementation of these skills in their teaching and learning. This qualitative study of 2 Malaysian school administrators is hoped to be able to identify the school administrators' awareness of the 21 st century skills and ascertain the implementation of the skills in the classroom activities from the administrators' perspective. The results obtained will be used as a preliminary data for the study conducted on school teachers.
\end{abstract}

Keywords-Malaysian teachers; school administrators; awareness; 21st century skills; ICT in education; teaching strategies;

\section{INTRODUCTION}

This study intends to discover what school administrators know about the 21 st century learning skills and how these skills are implemented in the English language classroom.

In order to ensure a smooth teaching and learning process, we first must identify whatteachers mean by 21 st-century education illustrated in this study. Most educators do not consider that the principles of the 21 st-century education movement are something new. Thus, this study will begin by covering an overview of the framework for 21 st Century Learning developed by the Partnership for 21st Century Learning (P21).

P21 aim to ensure and increase students' "engagement in the learning process" and later "graduate better prepared" to thrive in the challenging world today. although the various table text styles are provided. The formatter will need to create these components, incorporating the applicable criteria that follow.

\section{A. Background and context}

In order to ensure the competitiveness and engagement in the new and rapidly changing global environment, it is vital to shift the education of the new generation towards 21 st century teaching and learning.

So, appropriate amount of attention should be given to providing the suitable 21 st century content and skills to our learners and to make sure that the pedagogy used by teachers will produce the desired outcomes that are in line with the national education policy.

Commitment to this cause can be seen in the organization known as Partnership for 21 st Century Skills (P21). It is an American based organization whereby it's mission is "to serve as a catalyst to position 21 st century readiness at the centre of US K12 education by building collaborative partnerships among education, business, community and government leaders" (Partnership for 21st Century Skills, n.d.a). Although Malaysia does not have an organization as this, the Ministry of Education has listed several skills pertaining to the $21 \mathrm{st}$ century teaching and learning in its National Education Blueprint. In the National Education Blueprint, the aspirations listed were: Knowledge, Thinking skills, Leadership skills, Bilingual proficiency, Ethics and spirituality and National identity. So, for the context of this research, I, the researcher, would be looking at both the framework for 21 st century learning provided by Partnership for 21 st Century Learning (America) and the National Education Blueprint (Malaysia).

The Partnership for 21st Century Learning has developed a framework for 21 st century learning by identifying the core content, 21 st century themes and skills necessary for students to succeed in today's global workforce and communities. 
The six major elements that make up this framework include a focus on core subjects, 21 st century content, learning and innovation skills, information, media and technology skills, life and career skills, and 21st century assessments (Partnership for 21st Century Skills, 2009). Other components of 21 st century learning use an interdisciplinary approach to incorporate project- and problem-based learning and to promote learning in context and within a collaborative setting (Educational Origami, n.d.a).

\section{B. Problem Statement}

Over the years, there has been many efforts by the Ministry of Education of Malaysia to introduce and integrate the 21 st century skills into the nation's education. An example would be the outcomes that were listed as the student aspirations in the Malaysia

Education Blueprint 2013 - 2025. The aspirations listed are: knowledge, thinking skills, leadership skills, bilingual proficiency, ethics and spirituality, and national identity. [1] Another effort by the ministry is that teachers are periodically sent to courses and talks that covers the implementations of activities that is in line with 21 st century learning skills.

During my time as an educator, I had been periodically sent to countless above-mentioned events. Thus, I would assume that most in-service teachers and school administrators are exposed to, if not well-versed with the 21 st century teaching strategies through these numerous professional development workshops conducted by the ministry of education, not mentioning the literatures that they have read, or instructions which been given by their superiors.

Despite the efforts by the ministry, there has been minimal implementations of the 21st century skills in the classroom context in Malaysia. One aspect focused in the 21 st century skills is the "collaboration" skill under the "Learning and Innovation Skills" which is listed in the Framework for 21st Century Learning. (Framework For 21st Century Learning, 2016) According to Rotherham\& Willingham (2009), activities which promote problem-based learning and projectbased learning permits students to collaborate, work on authentic problems, and get involved with the community. These activities are widely known and can be found in any pedagogical methods textbook. Despite the fact that teachers are familiar with them and believe they are effective in teaching the 21 st century skill - collaboration, the teachers don't use them in the classroom context. Thus, through this study, it is hoped that teachers' awareness and implementation of the 21 st century skills from the administrators' perspectives will be identified.

\section{Research Objectives}

For this study, there are two research objectives. They are as follows:

- To identify what school administrators understand about 21 st century learning skills

- To determine how teachers are incorporating $21 \mathrm{st}$ century learning skills in their classes (from the administrators' perspectives)

\section{LITERATURE REVIEW}

\section{D. $21^{\text {st }}$ century skills}

According to Partnership for 21st Century Skills (n.d.b), the core content of a 21 st century curriculum incorporates mathematics, science, history, geography, English, reading, world languages, arts, economics and government and civics. Furthermore, they "also believe schools must move beyond a focus on a basic competency in core subjects to promoting understanding of academic content at much higher levels by merging 21 st century interdisciplinary themes into core subjects. (Partnership for 21st Century Skills, n.d.b, para. 2). Some of the newer themes promote areas such as global awareness, financial, economic, business and entrepreneurial literacy, and civic, health and environmental literacy. Additionally, as students are in the digital age, it is vital that they are good at using technology. Students must be able to manage the endless and huge quantities of information that is presented to them through the various media outlets available to them (Educational Origami, n.d.a). Pertaining to teaching, learning and innovation skills, educators must instruct students in the $4 \mathrm{Cs}$ - critical thinking and problem solving, creativity and innovation, communication and collaboration (Partnership for 21st Century Skills, 2011a). Lastly, teachers must also prepare students for both life and work after graduation. This can be done by assisting them in cultivating life and career skills such as flexibility and adaptability, initiative and selfdirection, social and cross-cultural skills, productivity and accountability and leadership and responsibility (Partnership for 21st Century Skills, 2011a)..

\section{E. 21st Century Education: Essential Components}

Based on the elements that comprise 21 st century teaching and learning, it can be said that the 21 st century education is not so different from what was offered to students in the previous century, but more accurately a series of adaptations and amendments to what was done in the past plus a movement towards a new approach to teaching and learning that caters to the current learning needs of the students (Jacobs, 2010c). There are 12 aspects that is looked upon when considering the movement of education in the America. These are "Interaction", "Assessment \& Feedback", "Centricity", "Curriculum \& Learning Focus", "Teaching Approach \& Methodologies", "Learning Relevance", "Thinking Skills", "Technology Use", "Learning Styles", "Grading/Reporting Systems, Timing of Learning", and "School Design".

\section{F. 21st Century Skills and Content}

In order to ensure that the $21 \mathrm{st}$ century education is significant in creating smooth teaching and learning process, the classroom activities should be related to real-world issues, problem and project-based, interdisciplinary, personalized, engaging, differentiated, flexible, inclusive, learner-centred, reflective, involves cooperation and collaboration among the pupils. Other than that, it also calls for accountability of performance and results from the various stakeholders. Thus, specific contents and skills are required to support such classroom activities. Most 21 st century advocates would come to an agreement that a strong 21 st century curriculum would 
emphasize on providing strong content and skills instruction to students. Cookson (2009) explains:

To successfully face rigorous higher-education coursework and a globally competitive work environment, schools must align classroom environments and core subjects with $21 \mathrm{st}$ century skills. By combining both skills and content, educators can impart the expertise required for success in today's world (p.11)

For this paper we will be looking at the The Partnership for 21 st which "developed a unified, collective vision for $21 \mathrm{st}$ century learning that is used to strengthen the American high schools" (Partnership for 21st Century Skills, 2006, p. 10).

In the Framework for 21 st Century Learning, there are six elements that are listed as keys in promoting effective $21 \mathrm{st}$ century learning. The six elements are as follows: Core Subjects, 21st Century Content, Learning, Thinking and Innovation Skills, Information, Media and Technology Skills, Life and Career Skills, 21st Century Assessments.

\section{PROPOSED Methodology}

In this study, a qualitative design will be applied to identify what school administrators understand about 21 st century learning skills and how 21 st century learning skills are incorporatedin the classes. For this study, a semi-structured individual interview will be used to interview 2 administrators from 2 different schools. The participants' consent will be inquired before conducting the study. The results obtained for this study will then be used as a preliminary data for the coming study which will be conducted on school teachers.

\section{CONCLUSION}

In conclusion, $21^{\text {st }}$ century skills are crucial for the students being able to survive in the rapidly changing global environment in the near future. Thus, it is important for educators and stakeholders to be empowered with the knowledge of these skills and implement them in the classrooms. This study will provide data regarding what teachers understand about and the implementation of $21 \mathrm{st}$ century skills in the classrooms from the administrators' perspectives. Conducting such research could be a relevance stakeholders and educators in devising changes and improvements to the education system.

\section{ACKNOWLEDGEMENT}

This study was supported by Universiti Utara Malaysia.

\section{REFERENCES}

[1] Educational Origami. (n.d.a). 21st century pedagogy. Retrieved from http://edorigami.wikispaces.com/21st+Century+Pedagogy

[2] Educational Origami. (n.d.b). 21st century teacher. Retrieved from http://edorigami.wikispaces.com/21st+Century+Teacher

[3] Jacobs, H. H. (2010c). Upgrading the curriculum: 21st century assessment types and skills. In H. Hayes-Jacobs (Ed.), Curriculum 21 Essential education for a changing world (pp. 18-29). Alexandria, VA Association for Supervision and Curriculum Development.

[4] Malaysian Education Blueprint 2013 - 2025 (Preschool to PostSecondary Education). (2013). Putrajaya: Kementerian Pendidikan Malaysia.

[5] Partnership for 21st Century Skills. (n.d.a). Our mission. Retrieved from http://www.p21.org/about-us/our-mission

[6] Partnership for 21 st Century Skills (n.d.b). Core subjects and 21st century themes. Retrieved from http://www.p21.org/overview/skillsframework $/ 57$

[7] Partnership for 21st Century Skills. (n.d.d). Overview: FAQ. Retrieved from http://www.p21.org/overview/p21-faq

[8] Partnership for 21 st Century Skills. (2009). P21 framework definitions. Retrieved

from http://www.p21.org/storage/documents/P21_Framework_Definitions.pdf

[9] Partnership for 21st Century Skills. (2016). Framework for 21st century learning. Retrieved from http://www.p21.org/storage/documents/1._p21_framework_2-pager.pdf

[10] Rotherham, A., \& Willingham, D. (2009). 21st Century skills: The challenges ahead. Educational Leadership, 67(1), 16-21. 